\title{
Kinetic model of carbonate dissolution in Martian meteorite ALH84001
}

\author{
R. E. KOPP AND M. HUMAYUN* \\ Department of Geophysical Sciences, The University of Chicago, Chicago, IL 60637, USA. \\ * Corresponding author's e-mail address: hum8@midway.uchicago.edu \\ ph: (773) 834-1337; FAX: (773) 702-9505
}

Published in the Robert N. Clayton special issue of Geochimica et Cosmochimica Acta Submitted: May 16, 2002; Accepted in revised form: August 7, 2002

Citation: R.E. Kopp and M. Humayun (2003). Kinetic model of carbonate dissolution in Martian meteorite ALH84001. Geochim. Cosmochim. Acta 67, 3247-3256. doi:10.1016/S0016-7037(02)01114-6

Copyright (C) 2003 Elsevier Ltd. 


\begin{abstract}
The magnetites and sulfides located in the rims of carbonate globules in the Martian meteorite ALH84001 have been claimed as evidence of past life on Mars. Here, we consider the possibility that the rims were formed by dissolution and reprecipitation of the primary carbonate by the action of water. To estimate the rate of these solution-precipitation reactions a kinetic model of magnesite-siderite carbonate dissolution was applied and used to examine the physicochemical conditions under which these rims might have formed. The results indicate that the formation of the rims could have taken place in $<50$ years of exposure to small amounts of aqueous fluids at ambient temperatures. Plausible conditions pertaining to reactions under a hypothetical ancient Martian atmosphere $\left(1\right.$ bar $\left.\mathrm{CO}_{2}\right)$, the modern Martian atmosphere (8 mbar $\left.\mathrm{CO}_{2}\right)$, and the present terrestrial atmosphere $\left(0.35 \mathrm{mbar} \mathrm{CO}_{2}\right)$ were explored to constrain the site of the process. The results indicated that such reactions likely occurred under the latter two conditions. The possibility of Antarctic weathering must be entertained which, if correct, would imply that the plausibly biogenic minerals (single-domain magnetite of characteristic morphology, and sulfide) reported from the rims may be the products of terrestrial microbial activity. This model is discussed in terms of the available isotope data and found to be compatible with the formation of ALH84001 rims. Particularly, anticorrelated variations of radiocarbon with $\delta^{13} \mathrm{C}$ indicate that carbonate in ALH84001 was affected by solutionprecipitation reactions immediately after its initial fall (ca. 13,000 ago) and then again during its recent exposure prior to collection.
\end{abstract}




\section{INTRODUCTION}

ALH84001 is an orthopyroxenite meteorite, recovered from Allan Hills, Antarctica, in 1984, and later linked by oxygen isotope data to the Martian meteorites of the SNC clan (Clayton, 1993; Clayton and Mayeda, 1983, 1996; Mittlefehldt, 1994). Composed primarily of orthopyroxene, the meteorite contains a number of trace phases, including olivine, chromite, maskelynite, pyrite, and ferromagnesite carbonate (approximately $\mathrm{Mg}_{0.6} \mathrm{Fe}_{0.3} \mathrm{Ca}_{0.1} \mathrm{Mn}_{0.01} \mathrm{CO}_{3}$ ). Petrographic and compositional details have been reported by Mittlefehldt (1994, 1997), Treiman (1998) and Eiler et al. (2002). With the exception of the carbonates, which fill fractures (McKay et al., 1996) or occur in impact-melt veins (Scott, 1999), the minerals appear to be part of an original igneous assemblage.

Carbonate generally occurs in zoned "globules", discoid grains of magnesite from $\sim 50 \mu \mathrm{m}$ to $\sim 200 \mu \mathrm{m}$ in diameter and $\sim 10 \mu \mathrm{m}$ thick located on fracture surfaces in the meteorite (Romanek et al., 1995; McKay et al., 1996; Mittlefehldt, 1997; Treiman, 1998). These globules have single crystal cores composed of ferromagnesite that are surrounded by polycrystalline rims composed of thin alternating Fe-rich and Mg-rich bands (Eiler et al., 2002). The Fe-rich bands are composed of abundant magnetite grains, including some argued to resemble those produced by magnetotactic bacteria (McKay et al., 1996; Thomas-Keprta et al., 2000, 2001; Friedmann et al., 2001; cf. Buseck et al. 2001), as well as trace amounts of sulfide minerals including pyrrhotite and greigite (McKay et al., 1996). Carbonates also occur in veins, where they are accompanied by feldspathic glass and other trace phases (Mittlefehldt, 1997; Treiman, 1998; Scott, 1999; Eiler et al., 2002). Such carbonates are composed of ankeritic cores, with a rim sequence similar to those described above (e.g., Eiler et al., 2002), and are the carbonates 
most frequently encountered in thin sections and studied by microscopic investigations. Eiler et al. (2002) drew attention to the differences between these two types of carbonate occurrence in ALH84001. The studies of McKay et al. (1996) focussed on carbonates exposed on fracture surfaces.

McKay et al. (1996) proposed that ALH84001 contained evidence for past life on Mars based on the following lines of argument: (1) the presence of secondary minerals (carbonates) in an igneous meteorite, supported by (2) a younger formation age of the carbonates; (3) the presence of elongate ovoids resembling terrestrial bacterial microfossils associated with carbonate phases; (4) the presence of magnetites and sulfides, in association with the carbonates, which can form as a product of biological activity on Earth; and (5) organic carbon in the form of polycyclic aromatic hydrocarbons (PAHs) within the meteorite. McKay et al. (1996) considered the possibility that some of these features might have been produced in Antarctica ( $\mathrm{p}$. 929), but dismissed it on the grounds that sulfate-reducing conditions were not known to occur in the ice sheets. Subsequent researchers have argued that the PAHs could be a product of a combination of terrestrial contamination, formation during impact heating, and delivery to the Martian surface by meteoritic or cometary debris (Becker et al., 1997, 1999; Jull et al., 1998). Bradley et al. (1997) concluded that the alleged microfossils were abiogenic structures. Studies of the magnetites in ALH84001 carbonates have found evidence the some of the magnetites were whiskers or platelets of abiogenic vapor-deposited origin (Bradley et al., 1996; cf. Taylor et al., 2000), while Thomas-Keprta et al. (2000) argued that a fraction of the magnetites were of distinctly biological origin resembling magnetites from magnetotactic bacteria (cf. Buseck et al., 2001). Of McKay et al.'s original arguments, the most resilient has been their interpretation of magnetite-sulfide assemblages in the globule rims. Thus, the interpretation of the McKay et al. 
(1996) evidence is intimately associated with the origin of the carbonate rim assemblages.

A number of alternative hypotheses about the origin of the carbonate globules have been proposed, most of which regarded the rims as cogenetic with the precipitation of the central carbonates. Harvey and McSween (1996) suggested the globules formed from a hightemperature interaction between $\mathrm{CO}_{2}$-rich fluids and orthopyroxene, with rapid cooling preserving the disequilibrium exhibited in the zonation of the rims. A different model by McSween and Harvey (1998) proposed that the globules formed at low temperature from an evaporating brine infiltrating impact crater fractures, with zonation reflecting sudden changes in the precipitation environment. Warren (1998) suggested a similar process, with the globules forming as flood evaporites, possibly in a playa lake-type environment. Treiman (1998) suggested that carbonate-depositing fluids replaced crystalline feldspar and feldspathic glass with carbonate. Brearley (1998) proposed that ALH84001 rim magnetites formed by thermal decomposition from an original siderite-rich rim during impact heating events. Scott (1999) proposed that the carbonates originally formed as evaporites, and were later subject to impact shock heating and partial vaporization, during which the magnetites formed. Golden et al. (2000, 2001) proposed a mildly hydrothermal origin at temperatures around $150^{\circ} \mathrm{C}$, with zonation resulting from a change in solution composition due to the precipitation of kinetically-favored carbonates, with magnetites forming by siderite decomposition during a brief heating at $470^{\circ} \mathrm{C}$. Each of these workers accepted a purely Martian origin for the carbonate rim assemblages.

We consider here the possibility that traces of meltwater, either on Mars or in Antarctica, entered the fractures, reacted with the carbonates to produce solution-reprecipitation products, and were subsequently removed by sublimation or evaporation. Under appropriate redox conditions the siderite component could be reprecipitated as magnetite. This paper considers the 
rate at which an aqueous fluid reacts with ferromagnesite carbonate, and the nature of the minerals redeposited. It describes the results of a kinetic model used to determine the rates and conditions required for secondary processes involving aqueous fluids to produce the rim mineral assemblages. It also addresses the possible sites for such processes, including the possibility of weathering reactions during surface exposure in Antarctica. The available isotope evidence is examined for constraints on the possible sites.

\section{METHODOLOGY}

The ALH84001 carbonates are mainly a solid solution of magnesite $\left(\mathrm{MgCO}_{3}\right)$ and siderite $\left(\mathrm{FeCO}_{3}\right)$, so the dissolution rates of the end-members (Pokrovsky and Schott, 2002) were modeled. Modeling calculations were carried out under a closed system assumption without imposed buffers, except for those reactions that were buffered by the presence of carbonate.

Magnesite surface speciation and magnesite and siderite dissolution rates were modeled using PHREEQC, a program publicly available from the USGS (Parkhurst and Appelo, 1999). For equilibrium calculations, PHREEQC uses a modified version of the Newton-Raphson iterative method to simultaneously solve mass balance, activity, and thermodynamic equilibrium equations. For kinetic calculations, PHREEQC employs an individually defined time-stepped algorithm for the rate of each reaction.

The empirically determined $25^{\circ} \mathrm{C}$ stability constants for magnesite surface species from Pokrovsky et al. (1999) (TABLE 1), the solubility constants from the MINTEQ database (TABLE 2), the magnesite dissolution rate formula from Pokrovsky and Schott (1999), and the siderite dissolution rate formula from Dresel (1989) were used in the calculations. Following Pokrovsky 
and Schott (1999), magnesite dissolution was treated with a surface speciation model and the dissolution rate formula described as a function of the concentration of the surface species $>\mathrm{CO}_{3} \mathrm{H}^{0}$ and $>\mathrm{MgOH}_{2}^{+}$:

$$
R\left(m o l m^{-2} s^{-1}\right)=\left(10^{11.198} \cdot\left\{>\mathrm{CO}_{3} \mathrm{H}^{0}\right\}^{3.97}+10^{9.38} \cdot\left\{>\mathrm{MgOH}_{2}^{+}\right\}^{3.94}\right) \cdot(1-\exp (-4 A / \mathbf{R} T))
$$

where $\{>\mathrm{i}\}$ represents the concentration in $\mathrm{mol} \mathrm{m} \mathrm{m}^{-2}$ of surface species $>\mathrm{i}$ (the sign $>$ denotes a surface complex to distinguish it from other modes of occurrence of the complex, and should not be confused with an inequality), $\mathbf{R}$ is the gas constant, $T$ is temperature in degrees Kelvin, and $A$ is the chemical affinity for the reaction, defined as

$$
A=-\mathbf{R} T \ln \left(Q / K_{s p}^{0}\right)
$$

where $Q$ is the ion activity product and $K_{s p}^{o}$ is the magnesite solubility product. A surface species $>$ xy refers to an ion $x$ on the surface of the crystal and a complex $y$ to which it is weakly bonded.

Dresel (1989) measured the rate of siderite dissolution in salt-free water under reducing conditions that prevented the precipitation of ferric hydroxides. He conducted free drift experiments, in which $\mathrm{pH}$ was allowed to vary and the system was thus allowed to approach equilibrium, and $\mathrm{pH}$-stat experiments, in which the system was maintained far from equilibrium at a constant $\mathrm{pH}$ by the addition of $\mathrm{HCl}$. Unlike the magnesite dissolution rate formula, the siderite dissolution rate formula of Dresel (1989) is based upon macroscopic parameters, specifically the activities of $\mathrm{H}^{+}, \mathrm{Fe}^{+2}$, and $\mathrm{HCO}_{3}{ }^{-}$:

$$
R\left(m o l m^{-2} s^{-1}\right)=10^{-4.58}\left(a_{H^{+}}\right)^{0.75}-10^{-4.07}\left(a_{\mathrm{Fe}^{+2}} a_{\mathrm{HCO}_{3}^{-}}\right)^{0.75}
$$

where $a_{j}$ is the activity of aqueous species $j$. The results of Dresel (1989) appear to be in agreement with siderite dissolution rates summarized in Pokrovsky and Schott (2002).

The surface speciation model employed by PHREEQC is based upon that described by 
Dzombak and Morel (1990). This model used stability constants that account for non-ideality resulting from Coulombic interactions by inclusion of an electrostatic term:

$$
K_{\text {eff }}=K_{\text {int }} \cdot \exp \left(-\Delta z F \Psi_{s} / \mathbf{R} T\right)
$$

where $K_{\text {int }}$ is the intrinsic stability constant (given in TABLE 1), $\Delta z$ is the change in surface charge produced by a reaction, $F$ is Faraday's constant $\left(96,485 \mathrm{C} \mathrm{mol}^{-1}\right)$, and $\Psi_{s}$ is the surface potential. $\Psi_{s}$ was determined using the method of Borkovec and Westall (1983) to solve the PoissonBoltzmann equation and determine the composition of a diffuse layer of ions surrounding the surface. This method showed that $\Psi_{s} \approx 0$, so after the initial runs, models were run under the assumption that $K_{\text {eff }}=K_{\text {int }}$ and the computationally expensive diffuse layer calculation was omitted.

Because the rate equations available were for dissolution at $25^{\circ} \mathrm{C}$, all trials were run at this temperature. Magnesite and siderite become more soluble in colder water, and thus the maximum extent of dissolution should be greater at $0^{\circ} \mathrm{C}$ than $25^{\circ} \mathrm{C}$. Employing $0^{\circ} \mathrm{C}$ equilibrium constants increased the rate of dissolution while far from equilibrium by a factor of 1.2-1.3. The decrease in the reaction rates for magnesite at lower temperatures was estimated from the Arrhenius equation,

$$
\ln \left(\frac{\mathrm{k}_{1}}{\mathrm{k}_{2}}\right)=\frac{\mathrm{E}_{\mathrm{a}}}{\mathrm{R}}\left(\frac{1}{\mathrm{~T}_{2}}-\frac{1}{\mathrm{~T}_{1}}\right)
$$

where $\mathrm{k}_{1}$ is the dissolution rate at $0^{\circ} \mathrm{C}, \mathrm{k}_{2}$ is that at $25^{\circ} \mathrm{C}, \mathrm{E}_{\mathrm{a}}$ is the activation energy. The activation energies for magnesite and siderite dissolution were not available, so we used a value of $50 \mathrm{~kJ} / \mathrm{ml}$ for both based on the measured values for pure calcite, $46 \pm 4 \mathrm{~kJ} / \mathrm{mol}$ (Sjöberg and Rickard, 1984), and for brucite, $60 \pm 12 \mathrm{~kJ} / \mathrm{mol}$ (Jordan and Rammensee, 1996).

The model considered the cases of carbonate discs immersed in pure liquid water, in 
equilibrium with atmospheres of specified $\mathrm{CO}_{2}$ partial pressures. (The specific instances considered here do not include reaction with highly saline waters.) Using the appropriate rate equations, the sizes of the carbonate discs were tracked in 1-year steps over a period of 200 years. Each trial disc was defined by several different parameters: its composition (either pure magnesite or pure siderite), its radius, its surface area-to-volume ratio, the amount of liquid water, and the composition of the atmosphere with which the solution was in equilibrium.

The geometry used in the model was that of a disc, exposed to the solution on its sides, with a fixed height of $10 \mu \mathrm{m}$ and a variable radius based on observations of ALH84001 carbonates. The surface area-to-volume ratio of such a disc is $2 / r$, where $r$ is the radius of the disc. Values of $50 \mu \mathrm{m}, 75 \mu \mathrm{m}$, and $100 \mu \mathrm{m}$ were used for the initial value of $r$; the value of $r$ was recalculated as a function of the amount of carbonate remaining throughout the course of a run. In the case of the siderite trials, the surface area-to-volume ratio was used only in calculating the total loss of carbonate in each step; for the magnesite trials, it was also used in surface speciation calculations to determine the total number of surface sites. (Following Pokrovsky et al. (1999), a density of $18 \mu \mathrm{mol} / \mathrm{m}^{2}$ was assumed.) The value used in the surface speciation calculations was fixed at the beginning of each trial and was not updated during each step; by varying the initial value, this fixing of the surface area-to-volume ratio was found to introduce an error of about $25 \%$ into the calculations.

The water/rock ratio is a critical parameter for these calculations. The choice of radius and thickness of a disc determine its mass, which for a $100 \mu \mathrm{m}$ disc is about $1 \mu \mathrm{g}$. The water/rock ratio is then varied by specifying different volumes of water. The amount of water in which the disc was immersed was varied from $5 \mu \mathrm{L}$ to $1 \mathrm{~L}$. Three different atmospheric compositions were used: a terrestrial atmosphere with a $\mathrm{pCO}_{2}$ of 0.35 mbar, a modern Martian atmosphere with 8 
mbar $\mathrm{CO}_{2}$, and a hypothetical ancient Martian atmosphere with 1 bar $\mathrm{CO}_{2}$. The solutions were initially in equilibrium with the atmosphere, but were allowed to depart from this equilibrium as the system evolved in isolation from the atmosphere. Microbial activity was neglected.

\section{RESULTS}

In general, magnesite and siderite dissolve at fairly similar rates, although the two rates can differ by as much as a factor of four (FIG. 1). Within the range of values of interest to this study, changes in the surface area-to-volume ratios of the globules had little effect. Although increasing the surface area-to-volume ratio does increase the rate of dissolution, the factor of two difference in this ratio between a disc with a radius of $50 \mu \mathrm{m}$ and a disc with a radius of 100 $\mu \mathrm{m}$ does not produce a significant effect (FIG. 2). The timescales for dissolution of magnesite or siderite discs of a radius comparable to those in ALH84001 are of a decadal scale ( $\approx 50$ years). This is very short compared with the terrestrial residence time of $\approx 13,000$ years (Jull et al., 1995). Several factors affect the estimated dissolution timescale including, 1) that the actual temperatures of the reaction are $<25^{\circ} \mathrm{C}$, and 2) that the disc surface is not smooth. To estimate the effect of temperature, the Arrhenius equation was applied using $50 \mathrm{~kJ} / \mathrm{mol}$ for the activation energy of magnesite or siderite. This choice of activation energy slows down the reaction by as much as a factor of six at $0^{\circ} \mathrm{C}$. Taking into account the reverse solubility of carbonates (higher in colder water) increases the dissolution rate by factors of 1.2-1.3. The assumption of a smooth disc surface is probably unrealistic, but the true surface area is difficult to estimate. Rough natural surfaces of the dissolving carbonate discs would act to enhance the dissolution rates. Thus, we use the dissolution rate of pure magnesite or siderite at $25^{\circ} \mathrm{C}$ as an estimate of the 
natural carbonate dissolution rate with the proviso that the actual rate may be no more than an order of magnitude slower. The dissolution rates implied by the model are on the order of decades to centuries, but still much shorter than the terrestrial age of ALH84001.

Decreasing the amount of water in which a carbonate disc is immersed produces a significant effect. Immersed in $1 \mathrm{~L}$ of water, it will ultimately dissolve completely on timescales of 50-200 years. In smaller volumes of water, carbonate dissolution rate decreases due to the adsorption of carbonate ions on the rate-controlling metal hydrated centers, preventing the entire carbonate from dissolving. As Dresel (1989) noted, siderite dissolves to near equilibrium, stopping at a $\log \left(Q / K_{s p}^{o}\right) \approx-0.5$, where $Q / K_{s p}^{o}$ is the saturation index. On the other hand, magnesite ceases dissolution when it reaches a $\log \left(Q / K_{s p}^{o}\right) \approx-1.7$. This effect is clearly visible in the smaller water volume runs (FIG. 3).

Atmospheric $\mathrm{CO}_{2}$ partial pressure also has a significant effect. While the modern terrestrial atmosphere produces an initial solution $\mathrm{pH}$ of 5.7, a 1 bar $\mathrm{CO}_{2}$ atmosphere produces a $\mathrm{pH}$ of 3.9. The lower $\mathrm{pH}$ significantly increases the initial rate of both magnesite and siderite dissolution (FIG. 3C). In the case of magnesite, while almost all magnesium surface sites are hydrated at both $\mathrm{pH}$ values, a lower $\mathrm{pH}$ promotes the formation of $>\mathrm{CO}_{3} \mathrm{H}^{0}$ sites over $>\mathrm{CO}_{3}{ }^{-}$sites, thus increasing dissolution rate. In the case of siderite, the rate of dissolution far from equilibrium is almost entirely determined by $\mathrm{H}^{+}$activity. Over the course of a run, however, the $\mathrm{pH}$ of the solution can increase significantly; solutions in which magnesite discs were exposed to terrestrial carbon dioxide levels $(0.35 \mathrm{mbar})$ reached a steady state at $\mathrm{pH}$ levels around 9.3.

\section{DISCUSSION}


The interiors of the carbonate globules in ALH84001 are composed of magnesite, with significant amounts of $\mathrm{FeCO}_{3}$ and $\mathrm{CaCO}_{3}$. Mittlefehldt (1994) reported an average carbonate composition of $\mathrm{Mg}_{58.0} \mathrm{Sd}_{29.4} \mathrm{Cc}_{11.5} \mathrm{Rd}_{1.1}$. Since calcite dissolves several orders of magnitude faster than magnesite or siderite (van Cappellen et al., 1993; Pokrovsky and Schott, 2002), the $\mathrm{MgCO}_{3}$ and $\mathrm{FeCO}_{3}$ components of the globules will be the main regulators of the carbonate dissolution rates. The dissolution rate of a mixed carbonate such as the ferroan magnesite discs occurring in ALH84001 may be treated as a linear combination of the dissolution rates of its pure endmembers. Since magnesite and siderite dissolve at fairly similar rates, the ALH84001 carbonates will also dissolve at about the same rate.

The results of the kinetic model therefore suggest that a carbonate disc, composed primarily of magnesite, exposed to a sufficient amount of water initially in equilibrium with the terrestrial atmosphere, could be reduced in radius by $10 \mu \mathrm{m}$ in less than fifty years. A minimum of $50 \mu \mathrm{L}$ of water would be needed if this dissolution were to occur in a continuous period of time. If the carbonate were exposed to a larger volume of water, a $10 \mu \mathrm{m}$ reduction in radius would occur after about 25 years, but the carbonate would continue to dissolve (the armoring effect of magnetite has been neglected). Smaller amounts of water would suffice if repeating cycles of wetness and dryness occurred. If such exposure had occurred with water initially in equilibrium with the modern Martian atmosphere, less than thirty years of exposure to at least $10 \mu \mathrm{L}$ of water would be necessary (FIG. 3). Under a thick $\mathrm{CO}_{2}$ atmosphere, like that generally believed to have existed on ancient Mars (Pollack et al., 1987), the exposure would have had to be brief for the carbonate to survive $(<5$ years). We estimate that the uncertainties in the calculated rates amount to less than an order of magnitude, and the relationships among the relative durations should be fairly accurate. It should be noted from FIG. 5 that the rim assemblages of 
ALH84001 carbonates are not in equilibrium with the hypothetical ancient Martian atmosphere, as the stable $\mathrm{Fe}$ species would be siderite, not magnetite, at such high $\mathrm{pCO}_{2}$. The presence of magnetite indicates a $\mathrm{pCO}_{2}<10$ mbar, which is compatible with fluids that equilibrated with either the modern Martian atmosphere or the terrestrial atmosphere. The term "modern Martian atmosphere" is applied here to the Martian atmosphere with $\mathrm{pCO}_{2}<10$ mbar, and may correspond to a time period beginning with the onset of the Hesperian epoch at 3.7 Ga (Jakosky and Phillips, 2001). Settling the issue of the site of the magnetite-producing reactions requires information other than the rate model described above.

Given the rapid rate of magnesite-siderite carbonate dissolution, ALH84001 was likely exposed to Antarctic surface conditions before its discovery in 1984 for sufficient time to allow a $10 \mu \mathrm{m}$ annulus to dissolve. Jull et al. (1988) showed from ${ }^{14} \mathrm{C}$ analysis of nesquehonite found on the surface of the Antarctic chondrite LEW85320 that this carbonate had been forming over the thirty years prior to the meteorite's recovery, which implies that it had been exposed to surface conditions favorable for carbonate formation for at least this amount of time. It is therefore reasonable to suppose that many Antarctic meteorites were exposed by ice ablation to surficial conditions for a significant period of time before their collection. Krähenbühl et al. (1998) inferred from analysis of F enrichment that ALH84001 could have been exposed to the terrestrial atmosphere for as long as 500 years.

During the possible multidecadal to multicenturial period of exposure at the surface, liquid water produced during the austral summer could have infiltrated the carbonate-containing fractures within ALH84001. When the water evaporated or sublimed away, fine-grained magnesite like that of the carbonate rims would have been left behind. If too large an amount of water entered the rims, however, the fine-grained carbonate would not have been localized in 
the rims.

Water entering a fracture would dissolve $\mathrm{Mg}^{+2}, \mathrm{Fe}^{+2}$, and $\mathrm{CO}_{3}^{-2}$ ions (along with other trace components) from the carbonate. Liberated $\mathrm{Fe}^{+2}$ ions would react with free oxygen or sulfate to produce magnetite, even under extremely reducing conditions, as indicated by FIG. 4. The presence of magnetite, rather than other iron oxides such as goethite or hematite, in the carbonate rims constrains oxygen fugacity during the period of precipitation. The iron stability diagram (FIG. 4), constructed using the equilibrium constants listed in TABLE 3, shows that magnetite precipitation occurs only when oxygen fugacity falls below $10^{-69}$ bar. The presence of fine-grained sulfide minerals in the rims associated with the magnetite-rich zones indicates conditions favorable to sulfide formation. One possible source of sulfur would be dissolved sulfate from Antarctic meltwater that could be converted by sulfate-reducing bacteria in the fractures to $\mathrm{H}_{2} \mathrm{~S}$, which would then react with dissolved $\mathrm{Fe}^{+2}$ to form various sulfide minerals. The oxygen fugacity conditions for sulfate reduction also correspond to those for magnetite precipitation (FIG. 4).

\section{Isotopic Evidence}

If the ALH84001 carbonate rims formed in Antarctica, these rims should be isotopically distinct from the central carbonate grains, as the rims would have incorporated terrestrial carbon from atmospheric $\mathrm{CO}_{2}$ (bearing ${ }^{14} \mathrm{C}$ ), oxygen from meteoric water, and sulfur from atmospheric sulfate. Below, we examine the available isotope data for evidence that would constrain the site of rim production.

a) Oxygen isotopes: Valley et al. (1997) and Leshin et al. (1998) reported ion probe $\delta^{18} \mathrm{O}_{\mathrm{SMOW}} \approx$ +5 to $+25 \%$ for carbonates in thin sections, with the highest values associated with rim carbonates. Eiler et al. (2002) reported ion probe $\delta^{18} \mathrm{O}_{\text {SMOW }} \approx 0$ to $+21 \%$ o for carbonate interiors, 
and distinctly higher $\delta^{18} \mathrm{O}_{\text {SMOW }} \approx+13 \%$ to $+28 \%$ for rim carbonates. The water/rock ratios derived from the kinetic model above are $>10^{3}$, so that carbonates reprecipitated from fluids derived from Antarctic ice may be expected to be isotopically light. O'Neil et al. (1969) reported equilibrium fractionation factors for $\mathrm{Ca}, \mathrm{Sr}$, and $\mathrm{Ba}$ carbonates as a function of temperature. $\mathrm{A}$ linear fit to the relationship between cation mass and fractionation factor for the data of O'Neil et al. (1969) yielded an extrapolated value for $\Delta^{18} \mathrm{O}_{\text {magnesite-water }}$ of $+34.7 \%$ at $273 \mathrm{~K}$. Using the measured value of $\delta^{18} \mathrm{O}=-42 \%$ for ice from Allan Hills (Fireman and Norris, 1982), magnesites precipitated in equilibrium with meltwater would have $\delta^{18} \mathrm{O}=-7 \%$. Clayton and Mayeda (1988) carried out similar calculations for calcite from EETA79001 and recognized this as a difficulty for an Antarctic origin. However, terrestrial carbonates produced in Antarctica do not exhibit such low $\delta^{18} \mathrm{O}$ values, e.g., nesquehonite (or hydrous $\mathrm{MgCO}_{3}$ ) deposited on the surface of LEW 85320 , an ordinary chondrite, has $\delta^{18} \mathrm{O}=+17.9 \%$ (Grady et al., 1989). Knauth et al. (this volume) described a kinetic isotope effect in calcites deposited subaerially in desert environments on terrestrial basaltic flows, which exhibit $\delta^{18} \mathrm{O}=+24$ to $+32 \%$, that are significantly heavier than calcite inferred to be in equilibrium with ambient meteoric water. It is likely that magnesite-depositing fluids form as films of meltwater, that subsequently undergo severe evaporative enrichment, particularly exacerbated by the katabatic winds that drive ice ablation in the meteorite recovery areas (Nagata, 1978).

The various $\delta^{18} \mathrm{O}$ values characteristic of modern or ancient Martian weathering environments have not been measured. Clayton and Mayeda (1988) estimated the $\delta^{18} \mathrm{O}$ of juvenile Martian $\mathrm{CO}_{2}$ and water on the basis of equilibrium fractionation at $\mathrm{T}=1000^{\circ} \mathrm{C}$ with Martian silicates, the $\delta^{18} \mathrm{O}$ of which were known from measurements of the SNC meteorites (Clayton and Mayeda, 1983, 1996). Karlsson et al. (1992) found that water extracted from SNC 
meteorites exhibited $\Delta^{17} \mathrm{O}$ greater than that of the silicate portions of the same meteorites, also indicating that the Martian hydrosphere was not in isotopic equilibrium with the lithosphere. Farquhar et al. (1998) showed that the $\Delta^{17} \mathrm{O}$ of ALH84001 carbonate was greater than that of its host rock by $0.8 \%$. Thus, a direct test of an Antarctic or Martian origin of the carbonate rims could be provided by in situ determination of $\Delta^{17} \mathrm{O}$ of rim mineral assemblages.

b) Carbon isotopes: The $\delta^{13} \mathrm{C}$ of the rim magnesites should be significantly lower $(\approx+0$ $5 \%$ ) than those of the globule interiors $(\approx+40 \%)$ if the rims are Antarctic weathering products. The only available in situ $\delta^{13} \mathrm{C}$ values for rim magnesites were reported by Niles et al. (2002), for rims around an ankeritic carbonate enclosed in fused feldspathic glass, and were found to be heavier than core $\delta^{13} \mathrm{C}$ values of $+32 \%$ to $+42 \%$.

Jull et al. $(1995,1997)$ found that acid etching of carbonates released $\mathrm{CO}_{2}$ with $F_{m}\left({ }^{14} \mathrm{C}\right)$ values ranging from 0.027 to 1.00 , where $F_{m}\left({ }^{14} \mathrm{C}\right)$ is defined as the ratio of the concentration of ${ }^{14} \mathrm{C}$ in the sample to that of the terrestrial atmosphere in 1950 . This would be expected from a mixture of Martian carbon from the central grains and terrestrial carbon from the rims. Jull et al. (1995) estimated that initial cosmogenic ${ }^{14} \mathrm{C}$ in the carbonate, produced by spallation on ${ }^{16} \mathrm{O}$ while the meteorite was in transit from Mars to Earth, would have produced a level of ${ }^{14} \mathrm{C}$ equal to $4.3 \%$ of the 1950 terrestrial atmospheric level; since the meteorite landed on Earth, this value would have decayed to $F_{m}\left({ }^{14} \mathrm{C}\right)=0.009 . F_{m}\left({ }^{14} \mathrm{C}\right)$ values expected for terrestrial carbonate would range from about 0.20 for ${ }^{14} \mathrm{C}$ incorporated when the meteorite landed $\sim 13,000$ y.b.p. (Jull et al., 1995) to as high as 1.8 for post- $1950{ }^{14} \mathrm{C}$ due to atmospheric nuclear bomb testing. The concentration of ${ }^{14} \mathrm{C}$ is too low to allow for in situ measurements, and inferences from bulk measurements must be relied upon, instead.

The etching experiments by Jull et al. $(1995,1997)$ were carried out with acetic and 
phosphoric acid treatments, that could not have oxidized organic matter, and hence represent the $\delta^{13} \mathrm{C}$ of core and rim carbonates present in ALH84001. The experiments revealed the presence of one component that bears little or no ${ }^{14} \mathrm{C}$, with a $\delta^{13} \mathrm{C} \approx+40 \%$, interpreted by Jull et al. (1997) as indigenous Martian carbonate. Figure 6 shows a plot of $\mathrm{F}_{\mathrm{m}}\left({ }^{14} \mathrm{C}\right) v s . \delta^{13} \mathrm{C}$. A line joining the estimated Martian carbon isotope composition with that derived from the modern terrestrial atmosphere $\left(\mathrm{F}_{\mathrm{m}}\left({ }^{14} \mathrm{C}\right)=1.0-1.8\right)$ represents a possible series of mixtures between these two reservoirs. A second mixing line joins the compositions of estimated Martian carbonate with that of carbonate in equilibrium with terrestrial atmospheric $\mathrm{CO}_{2}$ at 13,000 years ago $\left(\mathrm{F}_{\mathrm{m}}\left({ }^{14} \mathrm{C}\right)=\right.$ 0.20). Data plotting between these two mixing lines represent mixtures of carbonate fractions among 1) original Martian carbonates, 2) 13,000 year old weathering products, and 3) weathering products produced during recent exposure. It can be seen in FIG. 6 that all but one of the data points available in the literature plot on or between these mixing lines, indicating the presence of both $13 \mathrm{kyr}$ Antarctic weathering products and modern weathering products. It should be noted that formation of rim magnesites by exposure to the Martian atmosphere would not exhibit any live radiocarbon, and may be indistinguishable from the core carbonates. Thus, the data in FIG. 6 conclusively establish the role of terrestrial weathering in their formation, but do not excluded the possibility of Martian formation of part of the rim assemblages. The kinetic model described here indicates timescales of carbonate solution-reprecipitation of 50-300 years implying that the ALH84001 meteorite may have experienced Antarctic weathering both prior to burial in the ice, and prior to collection. The data of Jull et al. $(1995,1997)$ shown in FIG. 6 corroborate the implications of this model.

c) Sulfur isotopes: in situ $\delta^{34} \mathrm{~S}$ measurements on pyrites in ALH84001 indicate that the majority of such grains exhibit a positive $\delta^{34} \mathrm{~S} \approx+2$ to $+8 \%$ (Shearer et al., 1996; Boctor et al., 
1998; Greenwood et al., 1997, 2000), but these grains bear no relation to the rim mineral assemblages, and may be part of the original igneous assemblage. Only two measurements of the fine-grained sulfide in ALH84001 rims are available (Greenwood et al., 2000), and they have $\delta^{34} \mathrm{~S} \approx-9.7 \%$. Such a fractionation is decidedly light, and compatible with the activity of sulfate-reducing bacteria, if the source sulfate had $\delta^{34} \mathrm{~S} \approx+21 \%$, similar to seawater sulfate (Schlesinger, 1991). Thus, sulfur isotopes tentatively imply the presence of terrestrial microbial activity compatible with an Antarctic origin of the rim sequences.

\section{Speculations on the origins of magnetites and sulfides}

Whether the carbonate rims formed on Mars or in Antarctica, it is reasonable to suppose that the magnetites and sulfides associated with the rims formed at the same time as the rims. From FIGS. 4 and 5, we see that magnetite can be abiotically produced by the proposed rim formation process. Some rim magnetite may also have been produced by magnetotactic bacteria living in the fluid that dissolved the carbonate. This could explain the resemblance, noted by Thomas-Keprta et al. (2000), of some of the magnetite crystals to those produced by the magnetotactic bacteria strain MV-1. It is also consistent with the presence of single domain magnetite grains reported by Weiss et al. (2000) from rim assemblages in ALH84001, previously known exclusively in biogenic magnetite.

The small quantity of sulfide minerals present in the rims may have similarly been produced by terrestrial sulfate-reducing bacteria within the rock on the trace sulfate present in Antarctic ice (Legrand, 1997). Steele et al. (2000) reported the presence of an Antarctic endolithic organism, Actinomycetes, in ALH84001 and thus provided microbiological evidence for colonization of this Martian meteorite by terrestrial biota.

Furthermore, while some of the pyrites exhibit mass-independent fractionation of sulfur 
isotopes, the small number of carbonate-associated sulfide grains measured so far have not (Greenwood et al., 2000). Mass-independent sulfur isotope fractionation has been observed in Archean and Paleoproterozoic samples and is believed to result from photochemical oxidation of atmospheric sulfur species to sulfate possibly because of the low levels of atmospheric oxygen prevailing then (Farquhar et al., 2000). Mass-independent fractionation therefore would not be expected if the rim sulfides formed by reduction processes on Earth.

In order for magnetite to form in preference to ferric oxide/hydroxide, the solution within ALH84001 must have had low oxygen fugacities; at $25^{\circ} \mathrm{C}, \mathrm{fO}_{2}$ of below $10^{-69}$ bar is required for magnetite, rather than hematite, to be the stable form of iron oxide. These conditions are compatible with sulfate reduction having occurred in the meteorite, as seen in FIG. 4. Such extremely low $\mathrm{fO}_{2}$ values are not compatible with air-saturated water but are known from sediment pore waters in reducing sediments (Drever, 1988). Such efficient removal of oxygen from the fluids dissolving the carbonate rim assemblages is surprising and may indicate a high level of biological activity within the fractures.

Previous workers have considered the preterrestrial origin of the rims to be certain (Treiman, 1998), but the model presented here reveals the plausibility of a terrestrial origin of the rim sequences. Such a scenario would easily account for the presence of biominerals in the rims providing a simple solution to the debate on evidence for signs of life in this meteorite.

\section{CONCLUSIONS}

Among the most resilient arguments by McKay et al. (1996) that ALH84001 bears evidence of former Martian life are their claims that the magnetites and sulfides associated with the 
globules, located in the rims of fracture-filling carbonate globules, resemble those that might be produced by biological activity.

The kinetic model described in this paper was used to 1) evaluate the timescale of magnesite-siderite dissolution by an aqueous fluid, and 2) constrain the possible sites where this may have occurred in the multibillion-year history of the ALH84001 meteorite on Mars and on Earth. The model indicates that small amounts of aqueous fluid with dissolved $\mathrm{CO}_{2}$, and low levels of dissolved oxygen, could have produced the rims on timescales of decades to centuries, compatible with

a) weathering under Antarctic conditions either,

i) following ALH84001's fall on the Antarctic ice and subsequent burial, or

ii) during exposure by ice ablation in the decades preceding its recovery in 1984 .

The model also revealed that,

b) such an event could have occurred at any time during its exposure on the Martian surface after the loss of the dense early atmosphere, and the resulting mineralogical features would be difficult to distinguish from those produced during Antarctic exposure.

Mixing relations between $\delta^{13} \mathrm{C}$ and $\Delta^{14} \mathrm{C}$ from stepped etching experiments on ALH84001 indicate that carbonates in ALH84001 were exposed to the terrestrial atmosphere both 13,000 years ago and during the present, consistent with the predictions of the kinetic model. Although, Antarctic exposure of the carbonate can be firmly established by the data, the presence of Martian weathering in the rim assemblages cannot be excluded on such evidence, since any rim carbonate equilibrated with the Martian atmosphere would not exhibit ${ }^{14} \mathrm{C}$.

Several important tests of an Antarctic origin that are testable with ion microprobe analysis 
of appropriate samples from fracture-filling carbonates, or microbiological investigations, are proposed below:

1. the $\delta^{13} \mathrm{C}$ of rim carbonates in fracture-filling carbonate globules should be lower than those of the core carbonates $(+40 \%)$, at around 0 to $+5 \%$.

2. in situ $\Delta \Delta^{17} \mathrm{O}$ measurements of rim carbonates and/or magnetites should yield a $\Delta \Delta^{17} \mathrm{O}=$ $0 \%$, compatible with a terrestrial source of the fluid. The precision required for a conclusive measurement would be about $\pm 0.2-0.3 \%$ o $(2 \sigma)$, sufficient to resolve the values of the core carbonate from that of the rims.

3. Microbiological tests of ALH84001 should indicate the presence of sulfate-reducing microbes associated with carbonate surfaces.

If magnetite in the ALH84001 rims were formed in Antarctica, it would require the $\mathrm{fO}_{2}$ of the dissolving fluid to be compatible with sulfate reduction, which could have produced the sulfides associated with the carbonate rims. Such a reduction in the $\mathrm{fO}_{2}$ of a terrestrial fluid in contact with the atmosphere might require the presence of biological activity in the fractures. If this model is correct, then the apparently biogenic features in the carbonate globule rims (McKay et al., 1996) may be the product of microbial activity on Earth. Such a conclusion would be expected for terrestrial weathering, given that microbes mediate the terrestrial $\mathrm{Fe}$ redox cycle (Ehrlich, 1996). 
Acknowledgements. This paper is dedicated to Robert N. Clayton on the occasion of his retirement from the faculty of The University of Chicago. This study was made possible by the loan of ALH84001 samples by NASA Johnson Space Center and the Meteorite Working Group. We are particularly thankful to Marilyn Lindstrom for her efforts as curator at JSC. Discussions with Conel Alexander, David Archer, Nabil Z. Boctor, Robert N. Clayton, Joseph Kirschvink, Stephen Mojzsis, Ken Nealson, Andrew Steele, and Benjamin Weiss illuminated various aspects of this work. We thank Oleg S. Pokrovsky and two anonymous reviewers for comments that greatly improved the manuscript, and Greg Herzog for editorial handling. Partial support through NASA NAG 5-9800 (MH) is acknowledged. 


\section{REFERENCES}

Becker L., Glavin D.P., and Bada J. L. (1997) Polycyclic aromatic hydrocarbons (PAHs) in Antarctic Martian meteorites, carbonaceous chondrites, and polar ice. Geochim. Cosmochim. Acta 61, 475-481.

Becker L., Popp B., Rust T., and Bada J. L. (1999) The origin of organic matter in the Martian meteorite ALH84001. Earth Planet. Sci. Lett. 67, 71-79.

Boctor N. Z., Wang J., Alexander C. O. A., Hauri E. H., Bertka C. M., Fei Y. and Humayun M. (1998) Petrology and hydrogen and sulfur isotope studies of mineral phases in Martian Meteorite ALH84001. Lunar Planet. Sci. Conf. XXIX, abstract \#1787, LPI, Houston (CDROM).

Borkovec M. and Westall J. (1983) Solution of the Poisson-Boltzmann equation for surface excesses of ions in the diffuse layer at the oxide-electrolyte interface. J. Electroanalyt. Chem. 150, 325-337.

Bradley J. P., Harvey R. P. and McSween H. Y. (1996) Magnetite whiskers and platelets in the ALH84001 Martian meteorite: Evidence for vapor phase growth. Geochim. Cosmochim. Acta 60, 5149-5155.

Bradley J. P., Harvey R. P., McSween H. Y., Gibson E., Thomas-Keprta K., and Vali H. (1997) No 'nanofossils' in Martian meteorite. Nature 390, 454-456. 
Brearley A. J. (1998) Magnetite in ALH84001: Product of the decomposition of ferroan carbonate. Lunar Planet. Sci. XXIX. Lunar Planet. Inst., Houston. \#1451 (abstr.).

Buseck P. R., Dunin-Borkowski R. E., Devouard B., Frankel R. B., McCartney M. R., Midgley P. A., Pósfai M., and Weyland M. (2001) Magnetite morphology and life on Mars. Proc. Nat. Acad. Sci. 98, 13490-13495

Clayton R. N. (1993) Oxygen isotope analysis. In Antarctic Meteorite Newsletter 16(3) (eds. R. Score and M. Lindstrom). Johnson Space Center, Houston, p. 4.

Clayton R. N. and Mayeda T. K. (1983) Oxygen isotopes in eucrites, shergottites, nakhlites, and chassignites. Earth Planet. Sci. Let. 62, 1-6.

Clayton R. N. and Mayeda T. K. (1988) Isotopic composition of carbonate in EETA 79001 and its relation to parent body volatiles. Geochim. Cosmochim. Acta 52, 925-927.

Clayton R. N. and Mayeda T. K. (1996) Oxygen isotope studies of achondrites. Geochim. Cosmochim. Acta 60, 1999-2017.

Dresel P. E. (1989) The dissolution kinetics of siderite and its effect on acid mine drainage. Ph.D thesis, Pennsylvania State University.

Drever J. I. (1988) The Geochemistry of Natural Waters, 2nd Edition. Prentice Hall, Englewood Cliffs, NJ.

Dzombak D. and Morel F. (1990) Surface complexation modeling: Hydrous ferric oxide. John Wiley, New York. 
Ehrlich H. L. (1996) Geomicrobiology, 3rd Edition. Marcel Dekker, New York, pp. 312-388.

Eiler J. M., Valley J. W., Graham C. M., and Fournelle J. (2002) Two populations of carbonate in ALH84001: geochemical evidence for discrimination and genesis. Geochim. Cosmochim. Acta 66, 1285-1303.

Farquhar J., Thiemens M. H., and Jackson T. (1998) Atmosphere-surface interactions on Mars: $\Delta \Delta^{17} \mathrm{O}$ measurements of carbonate from ALH 84001. Science 280, 1580-1582.

Farquhar J., Bao H., and Thiemens M. (2000) Atmospheric influence of Earth's earliest sulfur cycle. Science 289, 756-758.

Fireman E. L. and Norris T. L. (1982) Ages and composition of gas trapped in Allan Hills and Byrd core ice. Earth Planet. Sci. Let. 60, 339-350.

Friedmann E. I., Wierzchos J., Ascaso C, and Winklhofer M. (2001) Chains of magnetite crystals in the meteorite ALH84001: Evidence of biological origin. Proc. Nat. Acad. Sci. 98, 2176-2181.

Golden D. C., Ming D. W., Schwandt C. S., Morris R. V., Yang S. V., and Lofgren G. E. (2000) An experimental study on kinetically-driven precipitation of calcium-magnesiumiron carbonates from solution: Implications for the low-temperature formation of carbonates in Martian meteorite Allan Hills 84001. Meteorit. Planet. Sci. 35, 457-465.

Golden D. C., Ming D. W., Schwandt C. S., Lauer Jr. H. V., Socki R. A., Morris R. V., Lofgren G. E. and McKay G. A. (2001) A simple inorganic process for formation of carbonates, magnetite, and sulfides in Martian meteorite ALH84001. Am. Mineral. 86, 370- 
375.

Grady M. M., Gibson Jr. E. K., Wright I. P., and Pillinger C. T. (1989) The formation of weathering products on the LEW 85320 ordinary chondrite: Evidence from carbon and oxygen stable isotope compositions and implications for carbonates in SNC meteorites. Meteoritics 24, 1-7.

Greenwood J. P., Riciputi L. R., and McSween Jr. H. Y. (1997) Sulfide isotopic compositions in shergottites and ALH84001, and possible implications for life on Mars. Geochim. Cosmochim. Acta 61, 4449-4453.

Greenwood J. P., Mojzsis S. J., and Coath C. D. (2000) Sulfur isotopic compositions of individual sulfides in Martian meteorites ALH84001 and Nakhla: implications for crustregolith exchange on Mars. Earth Planet. Sci. Lett. 184, 23-35.

Harvey R. P. and McSween H. Y. (1996) A possible high-temperature origin for the carbonates in the Martian meteorite ALH84001. Nature 382, 49-51.

Jakosky B. M. and Phillips R. J. (2001) Mars' volatile and climate history. Nature 412, 237-244.

Jordan G. and Rammensee W. (1996) Dissolution rates and activation energy for dissolution of brucite (001): A new method based on the microtopography of crystal surfaces. Geochim. Cosmochim. Acta 60, 5055-5062.

Jull A., Cheng S., Gooding J., and Velbel M. (1988) Rapid growth of magnesium-carbonate weathering products in a stony meteorite from Antarctica. Science 242, 417-419. 
Jull A. J. T., Eastoe C. J., Xue S., and Herzog G. F. (1995) Isotopic composition of the carbonates in the SNC meteorites Allan Hills 84001 and Nakhla. Meteoritics 30, 311-318.

Jull A. J. T., Eastoe C. J., and Cloudt S. (1997) Isotopic composition of carbonates in the SNC meteorites, Allan Hills 84001 and Zagami. J. Geophys. Res. 102, 1663-1669.

Jull A. J. T., Courtney C., Jeffrey D. A., and Beck J. W. (1998) Isotopic evidence for a terrestrial source of organic compounds found in Martian meteorites Allan Hills 84001 and Elephant Moraine 79001. Science 279, 366-369.

Karlsson H. R., Clayton R. N., Gibson E. K., Jr., and Mayeda T. K. (1992) Water in SNC meteorites: evidence for a Martian hydrosphere. Science 255, 1409-1411.

Knauth L. P., Brilli M., and Klonowski S. (2002) Isotope geochemistry of caliche developed on basalt with implications for ALH84001, the search for past life on Mars, and life in the Precambrian. Geochim. Cosmochim. Acta (this volume).

Krähenbühl U., Noll K., Döbeli M., Grambole D., Herrmann F., and Tolber L. (1998) Exposure of Allan Hills 84001 and other achondrites on the Antarctic ice. Meteorit. Planet. Sci. 33, $665-670$.

Legrand M. (1997) Ice-core records of atmospheric sulphur. Phil. Trans. Roy. Soc. London B 352, 241-250.

Leshin L. A., McKeegan K. D., Carpenter P. K., and Harvey R. P. (1998) Oxygen isotopic constraints on the genesis of carbonates from Martian meteorite ALH84001. Geochim. Cosmochim. Acta 62, 3-13. 
McKay D. S., Gibson Jr. E. K., Thomas-Keprta K. L., Vali H., Romanek C. S., Clemett S. J., Chillier X. D. F., Maechling C. R., and Zare R. N. (1996) Search for past life on Mars: Possible relic biogenic activity in Martian meteorite ALH84001. Science 273, 924-930.

McSween H. Y. and Harvey R. P. (1998) An evaporation model for formation of carbonates in the ALH84001 Martian meteorite. Intl. Geol. Rev. 40, 774-783.

Mittlefehldt D. W. (1994) ALH84001, a cumulate orthopyroxenite member of the Martian meteorite clan. Meteoritics 29, 214-221.

Mittlefehldt D. W. (1997) Macroscopic description of Allan Hills 84001 and the relative timing of events in its history (abstract). Meteorit. Planet. Sci. 32, A93.

Nagata T. (1978) A possible mechanism of concentration of meteorites within the meteorite ice field in Antarctica. Mem. Natl. Inst. Polar Res., special issue 8, 70-92.

Niles, P. B., Leshin L. A., Guan Y., and Hervig R. L. (2002) Carbon isotopic composition of ALH84001 carbonates: an ion microprobe study. Lunar Planet. Sci. XXXIII. Lunar Planet. Inst., Houston. \#1655 (abstr.).

O’ Neil J. R., Clayton R. N., and Mayeda T. K. (1969) Oxygen isotope fractionation in divalent metal carbonates. J. Chem. Phys. 51, 5547-5558.

Parkhurst D. and Appelo C. (1999) User's guide to PHREEQC (Version 2)-a computer program for speciation, batch-reaction, one-dimensional transport, and inverse geochemical calculations. Water-Resources Investigations Reports 99-4259. U.S. Geological Survey, 
Denver.

Pokrovsky O. S. and Schott J. (1999) Processes at the magnesium-bearing carbonates/solution interface. II. Kinetics and mechanism of magnesite dissolution. Geochim. Cosmochim. Acta 63, 881-897.

Pokrovsky O. S. and Schott J. (2002) Surface chemistry and dissolution kinetics of divalent metal carbonates. Env. Sci. Technology 36, 426-432.

Pokrovsky O. S., Schott J., and Thomas F. (1999) Processes at the magnesium-bearing carbonates/solution interface. I. A surface speciation model for magnesite. Geochim. Cosmochim. Acta 63, 863-880.

Pollack J. B., Kasting J. F., Richardson S. M., and Poliakoff K. (1987) The case for a wet, warm climate on early Mars. Icarus 71, 203-224.

Romanek C., Thomas K., Gibson Jr. E. K., McKay D., and Socki R. (1995) Petrogenesis of carbon and sulfur-bearing minerals in the Martian meteorite ALH84001. Lunar Planet. Sci. Conf. XXVI. Lunar Planet. Inst., Houston. \#1183 (abstr.).

Schlesigner W. (1991) Biogeochemistry: An analysis of global change. Academic Press, San Diego.

Scott E. R. D. (1999) Origin of carbonate-magnetite-sulfide assemblages in Martian meteorite ALH84001. J. Geophys. Res. 104, 3803-3813.

Shearer C. K., Layne G. D., Papike J. J., and Spilde M. N. (1996) Sulfur isotopic systematics in 
alteration assemblages in martian meteorite Allan Hills 84001. Geochim. Cosmochim. Acta 60, 2921-2926.

Sjöberg E. L. and Rickard D. T. (1984) Temperature dependence of calcite dissolution kinetics between 1 and $62^{\circ} \mathrm{C}$ at pH 2.7 to 8.4 in aqueous solutions. Geochim. Cosmochim. Acta $\mathbf{4 8}$, 485-493.

Steele A., Goddard D. T., Stapleton D., Toporski J. K. W., Peters V., Bassinger V., Sharples G., Wynn-Williams D. D., and McKay D. S. (2000) Investigations into an unknown organism on the Martian meteorites Allan Hills H4001. Meteorit. Planet. Sci. 35, 237-241.

Taylor A. P., Barry J. C., and Webb R. I. (2001) Structural and morphological anomalies in magnetosomes: possible biogenic origin for magnetite in ALH84001. J. Microscopy 201, 84106.

Thomas-Keprta K. L., Bazylinski D. A., Kirschvink J. L., Clemett S. J., McKay D. S., Wentworth S. J., Vali H., Gibson Jr. E. K., and Romanek C. S. (2000) Elongated prismatic magnetite crystals in ALH84001 carbonate globules: Potential Martian magnetofossils. Geochim. Cosmochim. Acta 64, 4049-4081.

Thomas-Keprta K. L., Clemett S. J., Bazylinski D. A., Kirschvink J. L., McKay D. S., Wentworth S. J., Vali H., Gibson Jr. E. K., McKay M. F., and Romanek C. S. (2001) Truncated hexa-octahedral magnetite crystals in ALH84001: presumptive biosignatures. Proc. Nat. Acad. Sci. 98, 21 64-2169. 
Treiman A. H. (1998) The history of Allan Hills 84001 revisited: Multiple shock events. Meteorit. Planet. Sci. 33, 753-764.

Valley J. W., Eiler J. M., Graham C. M., Gibson E. K., Romanek C. S., and Stolper E. M. (1997) Low-temperature carbonate concretions in the Martian meteorite ALH84001: evidence from stable isotopes and mineralogy. Science 275, 1633-1637.

Van Capellen P., Charlet L., Stumm W., and Wersin P. (1993) A surface complexation model of the carbonate mineral-aqueous solution interface. Geochim. Cosmochim. Acta 57, 3505-3518.

Warren P. H. (1998) Petrologic evidence for low-temperature, possibly flood evaporitic origin of carbonates in the ALH84001 meteorite. J. Geophys. Res. 103, 16759-16773.

Weiss B. P., Kirschvink J. L., Baudenbacher F. J., Vali H., Peters N. T., Macdonald F. A., Wikswo J. P. (2000) A low temperature transfer of ALH84001 from Earth to Mars. Science 290, 791-795. 


\section{TABLES}

TABLE 1. Internal stability constants used in model.

\begin{tabular}{lr}
\hline Reaction & $\log \mathrm{K}\left(25^{\circ} \mathrm{C}\right)$ \\
\hline$>\mathrm{CO}_{3} \mathrm{H}^{0}=>\mathrm{CO}_{3}{ }^{-}+\mathrm{H}^{+}$ & -4.65 \\
$>\mathrm{CO}_{3} \mathrm{H}^{0}+\mathrm{Mg}^{+2}=>\mathrm{CO}_{3} \mathrm{Mg}^{+}+\mathrm{H}^{+}$ & -2.20 \\
$>\mathrm{MgOH}^{0}=>\mathrm{MgO}^{-}+\mathrm{H}^{+}$ & -12 \\
$>\mathrm{MgOH}^{0}+\mathrm{H}^{+}=>\mathrm{MgOH}_{2}{ }^{+}$ & 10.60 \\
$>\mathrm{MgOH}^{0}+\mathrm{CO}_{3}{ }^{-2}+\mathrm{H}^{+}=>\mathrm{MgCO}_{3}{ }^{-}$ & 14.40 \\
$+\mathrm{H}_{2} \mathrm{O}$ & \\
$>\mathrm{MgOH}^{0}+\mathrm{CO}_{3}{ }^{-2}+2 \mathrm{H}^{+}=$ & 22.40 \\
$>\mathrm{MgHCO}_{3}{ }^{0}+\mathrm{H}_{2} \mathrm{O}$ & \\
\hline
\end{tabular}

A surface species $>x y$ refers to an ion $x$ on the surface of the crystal and a complex $y$ to which it is weakly bonded. For example, ' $>\mathrm{CO}_{3} \mathrm{H}^{0}$, represents a hydrogen atom bonded to a surface carbonate site.

Source: Pokrovsky et al. (1999) 
TABLE 2. Solubility constants used in model.

\begin{tabular}{|c|c|}
\hline Reaction & $\log \mathrm{K}\left(25^{\circ} \mathrm{C}\right)$ \\
\hline $\mathrm{MgCO}_{3}(\mathrm{~s})=\mathrm{Mg}^{+2}+\mathrm{CO}_{3}{ }^{-2}$ & -8.029 \\
\hline $\mathrm{FeCO}_{3}(\mathrm{~s})=\mathrm{Fe}^{+2}+\mathrm{CO}_{3}^{-2}$ & -10.55 \\
\hline $\mathrm{Mg}^{+2}+\mathrm{H}_{2} \mathrm{O}=\mathrm{MgOH}^{+}+\mathrm{H}^{+}$ & -11.79 \\
\hline $\mathrm{Mg}^{+2}+\mathrm{CO}_{3}^{-2}=\mathrm{MgCO}_{3}(\mathrm{aq})$ & 2.98 \\
\hline $\mathrm{Mg}^{+2}+\mathrm{H}^{+}+\mathrm{CO}_{3}^{-2}=\mathrm{MgHCO}_{3}^{+}$ & 11.40 \\
\hline $\mathrm{Fe}^{+3}+\mathrm{e}^{-}=\mathrm{Fe}^{+2}$ & 13.032 \\
\hline $\mathrm{Fe}^{+2}+\mathrm{H}_{2} \mathrm{O}=\mathrm{FeOH}^{+}+\mathrm{H}^{+}$ & -9.5 \\
\hline $\mathrm{Fe}^{+2}+2 \mathrm{H}_{2} \mathrm{O}=\mathrm{Fe}(\mathrm{OH})+2 \mathrm{H}^{+}$ & -20.57 \\
\hline $\mathrm{Fe}^{+2}+3 \mathrm{H}_{2} \mathrm{O}=\mathrm{Fe}(\mathrm{OH})_{3}^{-}+3 \mathrm{H}^{+}$ & -31 \\
\hline $\mathrm{Fe}^{+3}+\mathrm{H}_{2} \mathrm{O}=\mathrm{FeOH}^{+2}+\mathrm{H}^{+}$ & -2.19 \\
\hline $\mathrm{Fe}^{+3}+2 \mathrm{H}_{2} \mathrm{O}=\mathrm{Fe}(\mathrm{OH})_{2}^{+}+2 \mathrm{H}^{+}$ & -5.67 \\
\hline $\mathrm{Fe}^{+3}+3 \mathrm{H}_{2} \mathrm{O}=\mathrm{Fe}(\mathrm{OH})_{3}+3 \mathrm{H}^{+}$ & -13.6 \\
\hline $\mathrm{Fe}^{+3}+4 \mathrm{H}_{2} \mathrm{O}=\mathrm{Fe}(\mathrm{OH})_{4}^{-}+4 \mathrm{H}^{+}$ & -21.6 \\
\hline $2 \mathrm{Fe}^{+3}+2 \mathrm{H}_{2} \mathrm{O}=\mathrm{Fe}_{2}(\mathrm{OH})_{2}^{+4}+2 \mathrm{H}^{+}$ & -2.95 \\
\hline $3 \mathrm{Fe}^{+3}+4 \mathrm{H}_{2} \mathrm{O}=\mathrm{Fe}_{3}(\mathrm{OH})_{4}^{+5}+4 \mathrm{H}^{+}$ & -6.3 \\
\hline $\mathrm{CO}_{2}(\mathrm{~g})+\mathrm{H}_{2} \mathrm{O}=\mathrm{CO}_{3}^{-2}+2 \mathrm{H}^{+}$ & -18.16 \\
\hline $\mathrm{CO}_{3}^{-2}+\mathrm{H}^{+}=\mathrm{HCO}_{3}^{-}$ & 10.33 \\
\hline $\mathrm{CO}_{3}^{-2}+2 \mathrm{H}^{+}=\mathrm{CO}_{2}(\mathrm{aq})+\mathrm{H}_{2} \mathrm{O}$ & 16.681 \\
\hline
\end{tabular}

Source: MINTEQ database. 
TABLE 3. Standard Gibbs free energies and equilibrium constants used in stability diagrams.

\begin{tabular}{|c|c|c|}
\hline Reaction & $\Delta \mathrm{G}^{\circ}(\mathrm{kJ} / \mathrm{mol})$ & $\log \mathrm{K}\left(25^{\circ} \mathrm{C}\right)$ \\
\hline $\begin{array}{l}\mathrm{Fe}_{2} \mathrm{O}_{3} \text { (hematite) }+4 \mathrm{H}^{+}=2 \mathrm{Fe}^{+2} \\
+2 \mathrm{H}_{2} \mathrm{O}(\mathrm{l})+0.5 \mathrm{O}_{2}(\mathrm{~g})\end{array}$ & 97.2 & -17.0 \\
\hline $\begin{array}{l}\mathrm{Fe}_{3} \mathrm{O}_{4} \text { (magnetite) }+6 \mathrm{H}^{+}= \\
3 \mathrm{Fe}^{+2}+3 \mathrm{H}_{2} \mathrm{O}(\mathrm{l})+0.5 \mathrm{O}_{2}(\mathrm{~g})\end{array}$ & 48.0 & -8.40 \\
\hline $\begin{array}{l}2 \mathrm{Fe}_{3} \mathrm{O}_{4} \text { (magnetite) }+0.5 \mathrm{O}_{2}(\mathrm{~g}) \\
=3 \mathrm{Fe}_{2} \mathrm{O}_{3} \text { (hematite) }\end{array}$ & -195.8 & 34.30 \\
\hline $\begin{array}{l}\mathrm{Fe}_{3} \mathrm{O}_{4}(\text { magnetite })+3 \mathrm{H}_{2} \mathrm{O}(\mathrm{l})= \\
3 \mathrm{Fe}(\mathrm{OH})_{2}+0.5 \mathrm{O}_{2}(\mathrm{~g})\end{array}$ & 268.19 & -46.99 \\
\hline $\begin{array}{l}2 \mathrm{Fe}_{3} \mathrm{O}_{4}(\text { magnetite })+3 \mathrm{H}_{2} \mathrm{O}(\mathrm{l}) \\
+0.5 \mathrm{O}_{2}(\mathrm{~g})=6 \mathrm{FeO}(\mathrm{OH}) \\
\text { (goethite) }\end{array}$ & -190.01 & 33.290 \\
\hline $\begin{array}{l}2 \mathrm{Fe}_{3} \mathrm{O}_{4} \text { (magnetite) }+9 \mathrm{H}_{2} \mathrm{O}(\mathrm{k}) \\
+0.5 \mathrm{O}_{2}(\mathrm{~g})=6 \mathrm{Fe}(\mathrm{OH})_{3} \\
\text { (amorphous) }\end{array}$ & -14.03 & 2.458 \\
\hline $\begin{array}{l}\mathrm{FeCO}_{3} \text { (siderite) }+2 \mathrm{H}^{+}=\mathrm{Fe}^{+2} \\
+\mathrm{CO}_{2}(\mathrm{~g})+\mathrm{H}_{2} \mathrm{O}(\mathrm{l})\end{array}$ & -50.17 & 8.790 \\
\hline $\begin{array}{l}3 \mathrm{FeCO}_{3} \text { (siderite) }+0.5 \mathrm{O}_{2}(\mathrm{~g})= \\
\mathrm{Fe}_{3} \mathrm{O}_{4} \text { (magnetite) }+3 \mathrm{CO}_{2}(\mathrm{~g})\end{array}$ & -198.47 & 34.772 \\
\hline $\begin{array}{l}2 \mathrm{FeCO}_{3} \text { (siderite) }+0.5 \mathrm{O}_{2}(\mathrm{~g})= \\
\mathrm{Fe}_{2} \mathrm{O}_{3} \text { (hematite) }+2 \mathrm{CO}_{2}(\mathrm{~g})\end{array}$ & -197.58 & 34.616 \\
\hline $\mathrm{H}_{2}(\mathrm{~g})+0.5 \mathrm{O}_{2}(\mathrm{~g})=\mathrm{H}_{2} \mathrm{O}(\mathrm{l})$ & -237.13 & 41.545 \\
\hline $\mathrm{SO}_{4}^{-2}+2 \mathrm{H}^{+}=\mathrm{H}_{2} \mathrm{~S}+2 \mathrm{O}_{2}(\mathrm{~g})$ & 716.7 & -125.6 \\
\hline
\end{tabular}

Source: Gibbs free energies of formation from Drever (1988). 

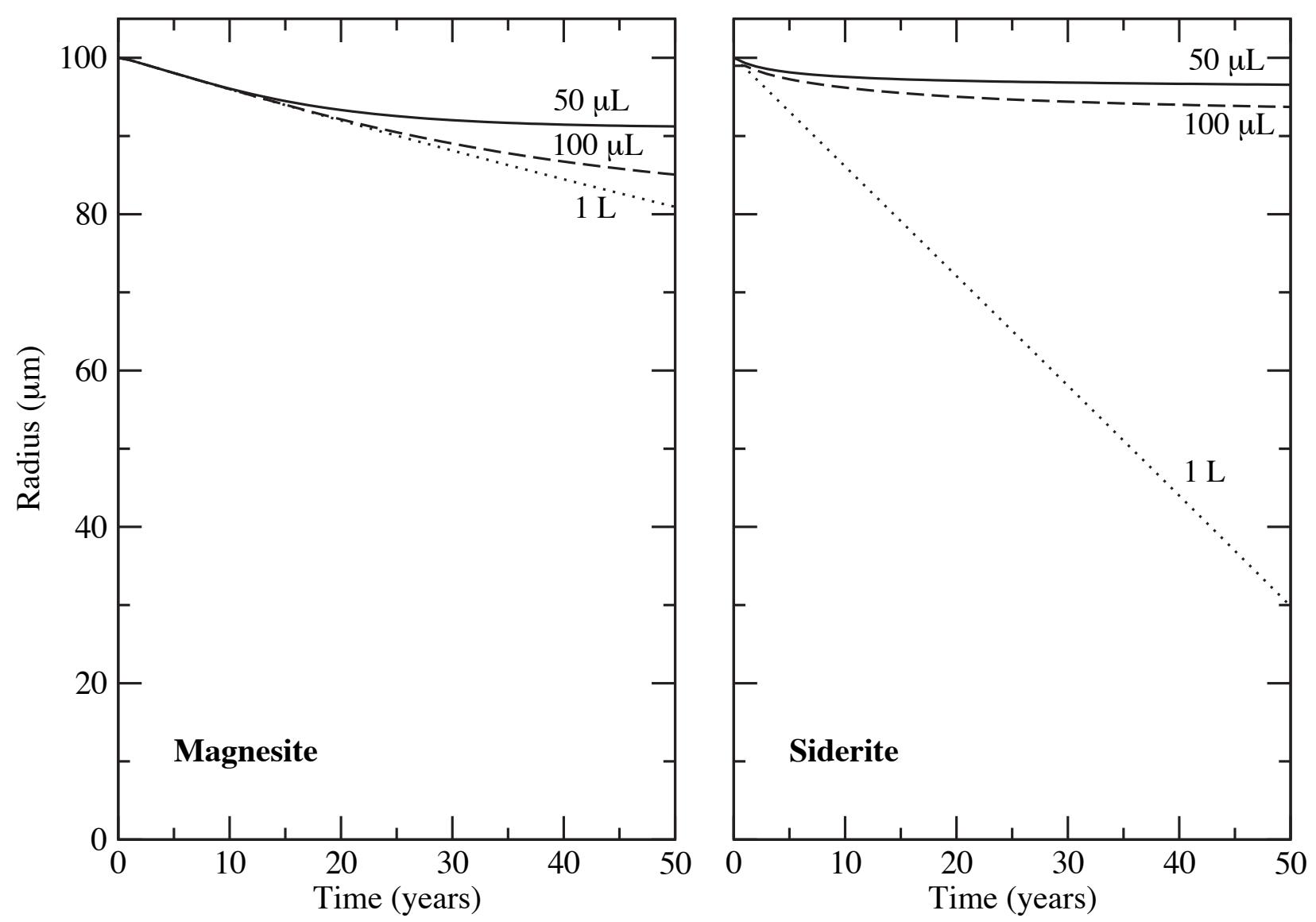

FIG. 1. Change in radius during dissolution of magnesite and siderite discs of $100 \mu \mathrm{m}$ initial radius in varying amounts of liquid water initially in equilibrium with an atmosphere containing $350 \mathrm{ppm} \mathrm{CO}_{2}$ at $25^{\circ} \mathrm{C}$. In each panel, dissolution of discs immersed in $50 \mu \mathrm{L} \mathrm{H}_{2} \mathrm{O}, 100 \mu \mathrm{L} \mathrm{H} \mathrm{H}_{2} \mathrm{O}$, and $1 \mathrm{~L} \mathrm{H}_{2} \mathrm{O}$ are shown from top to bottom. 


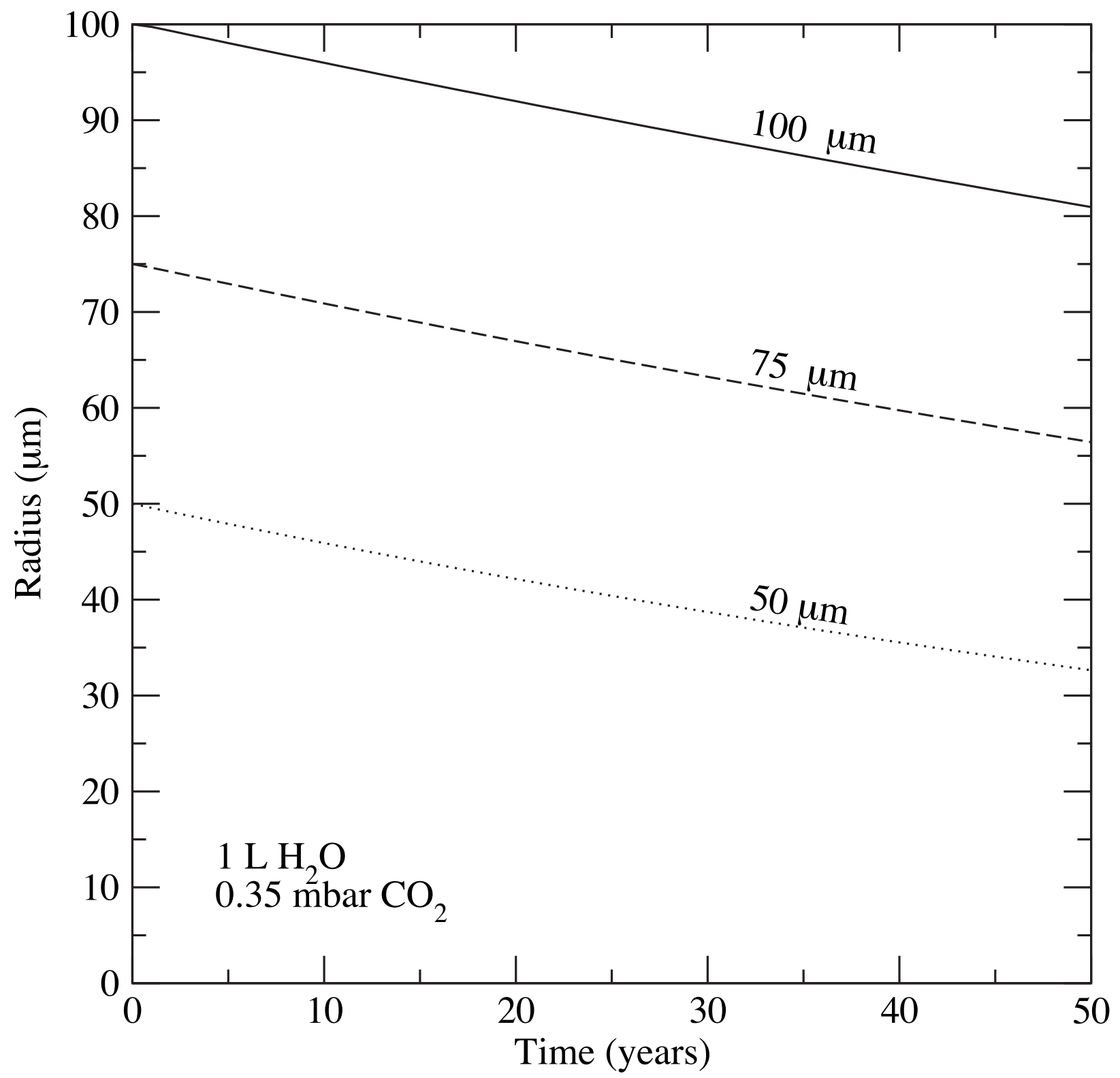

FIG. 2. Comparative rates of radial change of magnesite discs of varying initial radii in $1 \mathrm{~L}$ of liquid water initially in equilibrium with an atmosphere of terrestrial composition, containing $350 \mathrm{ppm} \mathrm{CO}_{2}$ at $25^{\circ} \mathrm{C}$. 

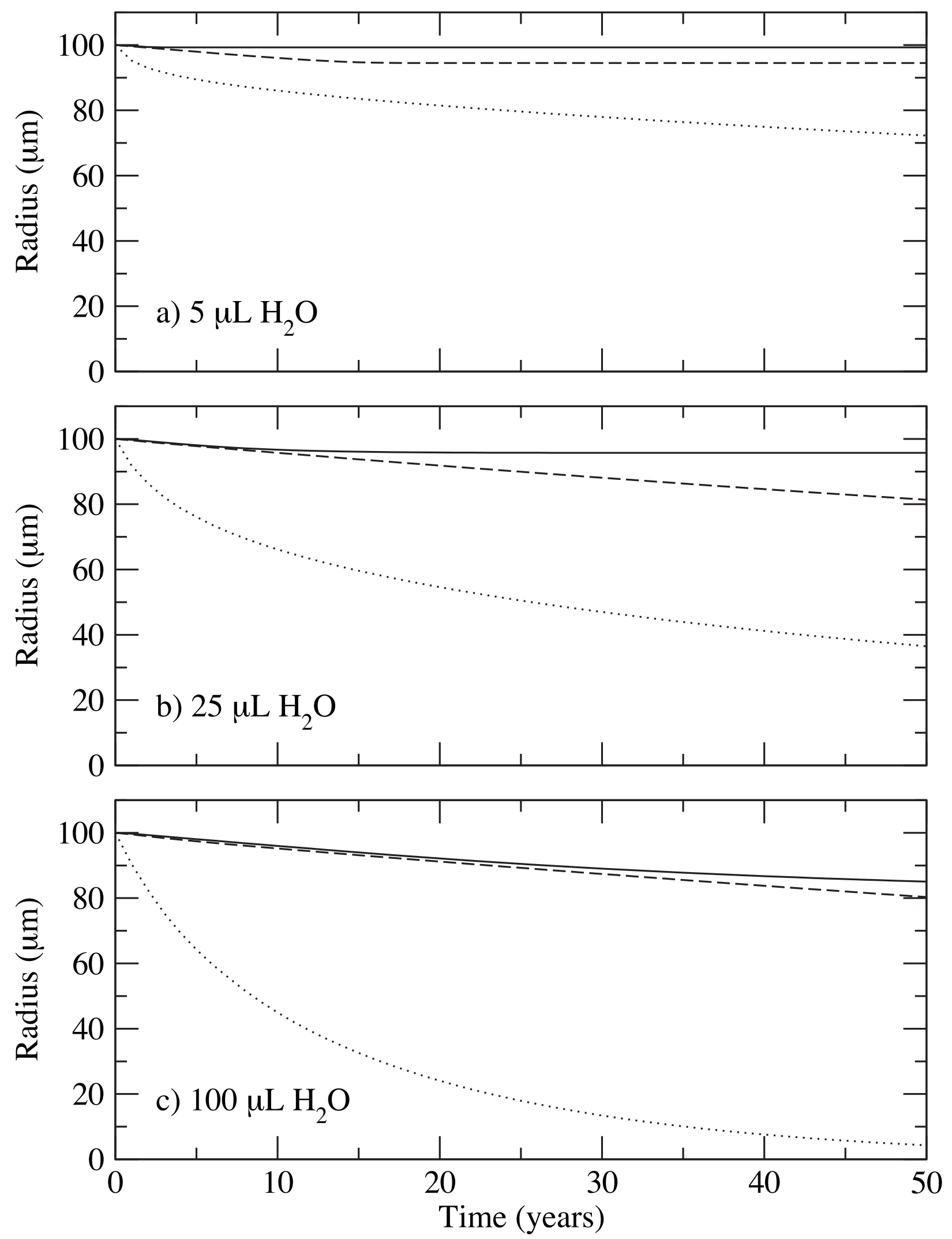

Fig. 3. Comparative rates of radial change for magnesite discs of $100 \mu \mathrm{m}$ initial radius immersed in a) $5 \mu \mathrm{L} \mathrm{H}_{2} \mathrm{O}$, b) $25 \mu \mathrm{L} \mathrm{H} \mathrm{H}_{2} \mathrm{O}$, and c) $100 \mu \mathrm{L} \mathrm{H}_{2} \mathrm{O}$, at $25^{\circ} \mathrm{C}$. In each panel are shown rates for solutions initially in equilibrium with solid curve: 0.35 mbar $\mathrm{CO}_{2}$, dashed curve: 8 mbar $\mathrm{CO}_{2}$, and dotted curve: 1 bar $\mathrm{CO}_{2}$. 


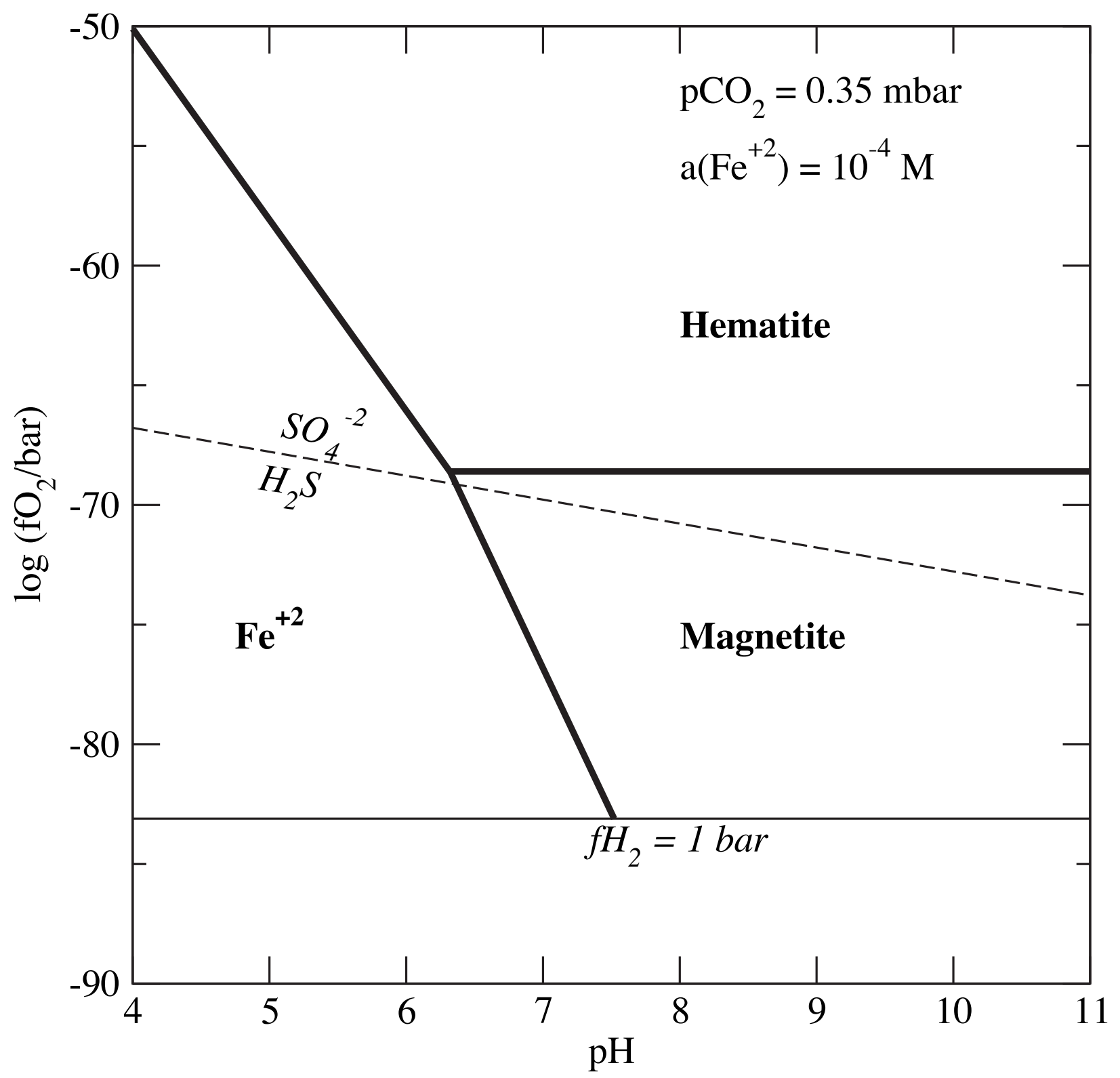

Fig. 4. Stability relations of iron exposed to liquid water at $25^{\circ} \mathrm{C}$, plotted as a function of $\mathrm{pH}$ and log oxygen fugacity. The dotted line marks conditions at which the concentrations of $\mathrm{SO}_{4}{ }^{-2}$ and $\mathrm{H}_{2} \mathrm{~S}$ are equal. The thin solid line marks the boundary of the water stability field, below which water will decompose to molecular hydrogen and oxygen. Relations are calculated for a solution with $\mathrm{Fe}^{+2}$ activity of $10^{-4} \mathrm{M}$, in equilibrium with an atmosphere containing $350 \mathrm{ppm}$ $\mathrm{CO}_{2}$ using the equilibrium constants listed in Table 3. 


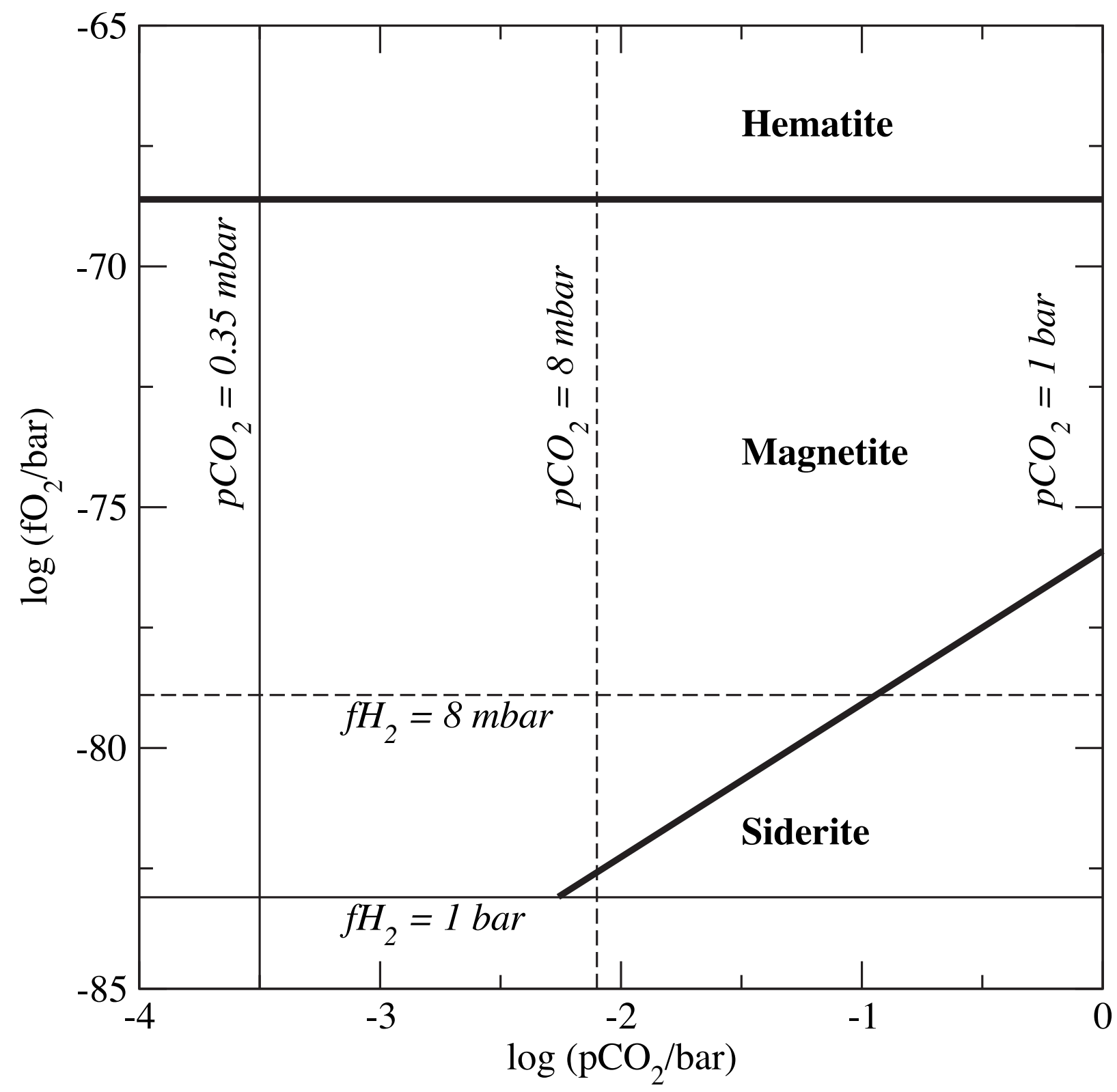

FIG. 5. Stability relations of iron exposed to liquid water at $25^{\circ} \mathrm{C}$, plotted as a function of carbon dioxide partial pressure and log oxygen fugacity. The thin solid lines mark terrestrial $\mathrm{pCO}_{2}$ and the boundary of the water stability field at 1 bar total pressure. The dotted lines mark modern Martian $\mathrm{pCO}_{2}$ and the boundary of the water stability field at 8 mbar total pressure. Ancient Martian atmosphere (1 bar) would plot at the right margin of the diagram. Relations are calculated for a solution with $\mathrm{Fe}^{+2}$ activity of $10^{-4} \mathrm{M}$, using the equilibrium constants listed in Table 3. 


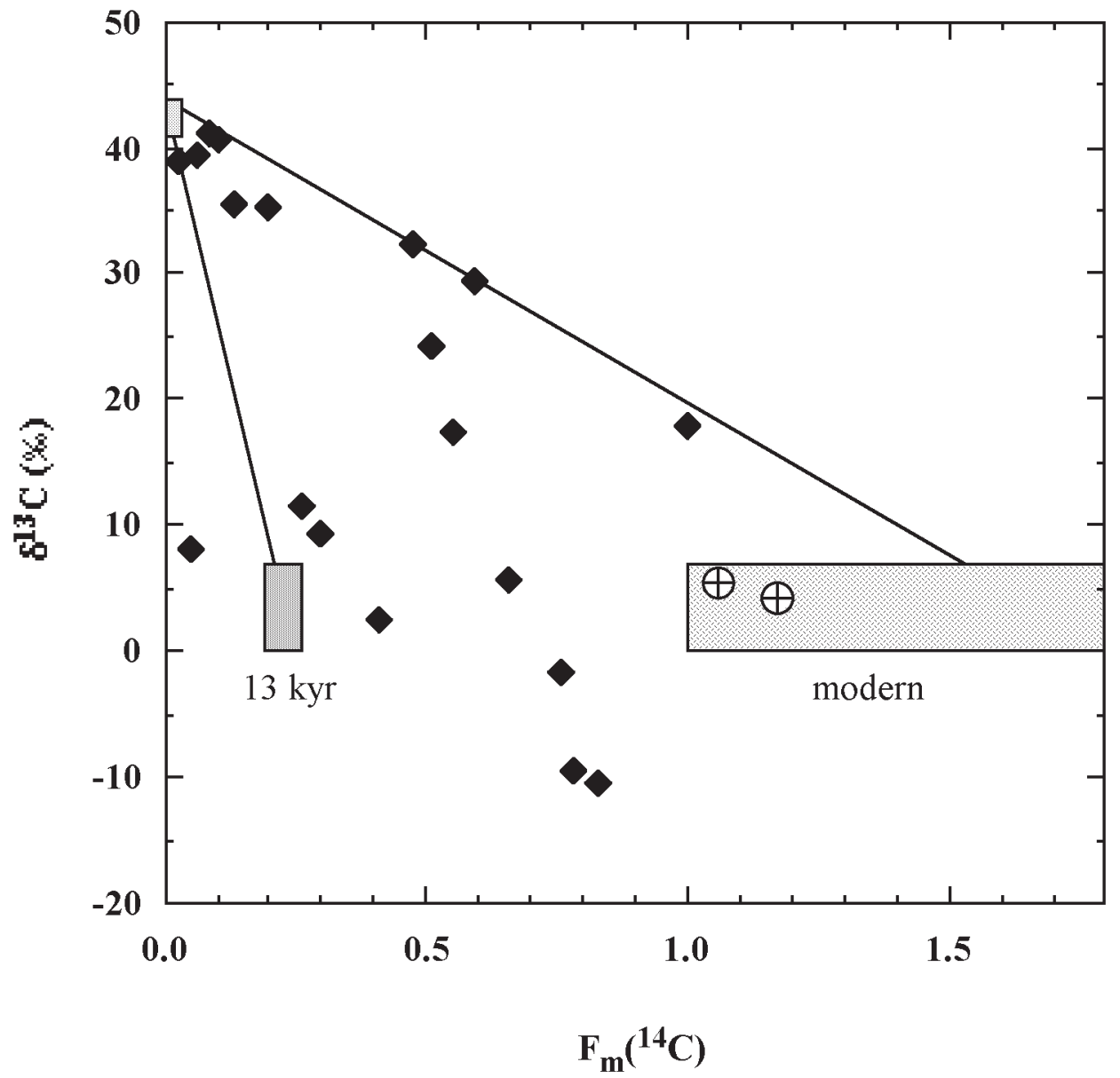

Fig. 6. $\delta^{13} \mathrm{C}$ vs. $\mathrm{F}_{\mathrm{m}}\left({ }^{14} \mathrm{C}\right)$ on $\mathrm{CO}_{2}$ from stepped etching experiments of Jull et al. $(1995,1997)$ on bulk ALH84001 fragments (solid diamonds). Following Jull et al. (1997), indigenous Martian carbonate is represented as stipled box with $\delta^{13} \mathrm{C} \approx+40 \%$, and virtually extinct ${ }^{14} \mathrm{C}$. Symbols: modern: carbonate with $\mathrm{C}$ isotopic composition of the modern atmosphere; $13 \mathrm{kyr}$ : carbonate isotopically equilibrated with the atmosphere 11,000-13,000 years ago; circles with crosses: Antarctic magnesite from LEW85320 (Jull et al., 1988). Mixing lines are shown between Martian carbonate and the two possible terrestrial endmembers. 